\section{8. $\mathrm{CO}_{2}$ レーザの生体防護器材に関する基 礎的検討}

\author{
東京都立広尾病院 口腔外科 \\ 長 沢明籁 \\ 東大 医用電子研 \\ 西川宏司渥美和彦 \\ 㭏吉田製作所 \\ 平柄喜章
}

レーザの医学における研究は急速に進展しており, その応用性は未知のものを含めてかなり広く大きなも のが期待されて㧍り，レーザは医療の技術革新をもた らそらとしている。 しかし一方レーザはその性格から みて使用法を誤まると危険性の大きなものでもある. したがってレーザを生体に応用する場合にはまずその 安全対策を優先して十分考えることが望ましい，

著者らはまず $\mathrm{SO}_{2}$ レーザ治療において，治療対象 部以外の生体表面をレーザの障害から保護するための 器材についての基礎的検討を行なったので報告する.

レーザープロテクターには (1)レーザ光を吸収して レーザの作用（透過）を抑制する吸収性防護材と（2) レーザ光を反射させることによってレーザの作用（透 過）を抑制する反射型防護材とが志る。著者らは $\mathrm{CO}_{2}$ レーザのプロテクターとして考えられる材質に $\mathrm{CO}_{2}$ レ 一ザを照射して，その下にある物（実験にはアクリル 樹脂ブロックを用いた）にレーザの作用が抑制される 程度を記録観察した。

吸収性防護材としては, 水を満したラバーバルーン がほぼ完全な防護効果を得た. また反射性防護材とし ては, アルミ箔などが良好な防護効果を得た. $\mathrm{CO}_{2}$ レ 一ザ手術などでは水がよく防護手段として用いられる が，水の層が薄い場合には $\mathrm{CO}_{2}$ レーザはこれを貫通す ることが実験的に証明されたので注意を要する．水を 含ませた薄手のラバーバルーンは, 臨床の応用性のあ るものであるが，着色水を入れておけば $\mathrm{CO}_{2}$ レーザの 誤照射の発見にも大きなメリットがある.

\section{9. 新しい炭酸ガスレーザープローブの開 発}

\section{東大 医用電子研 \\ 中島正治 井原章夫 渥美和彦}

レーザー発振装置, 導光路等の改良により炭酸ガス レーザーメスは大幅に小型化し，操作性も向上した。
我国においても既に数施設で臨床応用が始まっている 現状である。

レーザーメスを実際に使用するにあたって，先端プ ローブの形状㧍よび機能は手術操作に大きく影響す る. プローブの最少限備えていなければならない条件 として以下の事項が考えられる。

(1)集光レンズから対象物まで適切な距離を保つため の Spaier の存在 (2)切開などにより生じた煙を消散 させる Assist Gas Jet の存在 (3)集光レンズから対 象物までに不用意に術者の指などが入り込まないため の防護の必要 (4)切開部分がプローブによりさえぎら れず直視しながら操作が行えること.

これらの要求は既に発表されている各社のレーザー メスにおいてほぼ赛現されている。しかしながら実際 にこのレーザーメスプローブを用い，各手術手技につ いて検討した結果，種々の問題点が明らかになった。

これらの問題点のらち (1)開胸, 開腹等の操作に伴 う媣部臟器の副損傷をいかにして防ぐか (2)肝切除な ぞ実質臟器の切開において切開部が深部におよび必ず しも視野の展開が充分できない場合，いかにしてレー ザー光を適切に照射するか...この 2 点について今回検 討し新しい先端プローブを考案し試作した.

深部臓器の保護に関しては, 焦点以下のレーザー光 を吸収するための受け皿をもった形状のプローブを試 作した.

実質臟器の切開に関しては, プローブ先端を太く特 殊な形状とし，プローブの圧力で創の展開が行えるよ らなプローブを透明アクリルで作成した.

これらの新しく製作したプローブを用いて動物実験 を行った結果，手術操作の簡便化を認めたので報告す る.

\section{0. モレクトロン・Y A G・レーザーの基礎 的研究}

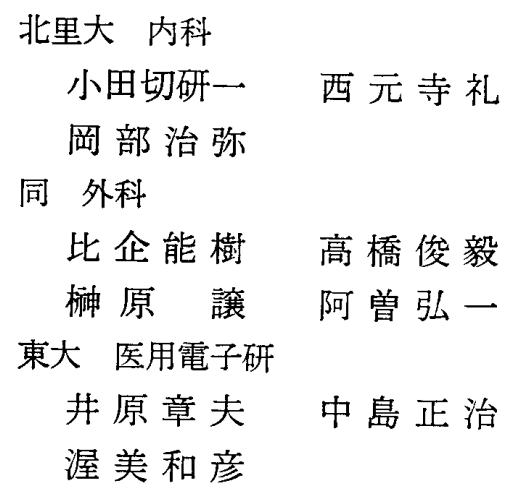

LASER 照射が組織止血に対して有効であると確か められている. 今回犬と家鬼を用いて消化管出血に照 
射した内視鏡レーザー凝固装置として，米国 Molectron Medical 社製Y A Gレーザー・モデル 8000につ いて報告する。モデル 8000 においては， $208 \mathrm{~V} ， 3$ 相, $40 \mathrm{~A}$ の電源にて, 最大出力約 $140 \mathrm{~W}$ の A Gレー ザー光を照射する．照射部位でのパワーは，1Wより 100W まで任意に調整可能で，照射時間も0.1〜9.9秒 まで，0.1秒ごとに可変できる．これらのレーザー出 力, 照射時間, 照射回数, 照射全エネルギーが瞬時に 器械操作パネルにデジタル表示される．ガイド光とし てキセノンランプを使用することにより組織と血液に 対して識別可能で，Y A Gレーザー光の非可視光を助 けている.アシストガスは，オプティカルファイバー の先端から噴射されて, ファイバ一先端の污染防止 と, 血液の除去に作用寸る。送入ガスは任意の設定值 より，自動的に回収されるシステムを有している。

オプティカル・ファイバーは，石英から作られてお り，その周囲をテフロンで被覆されている.ファイバ 一全体がディスポーザブルとなっているため, ファイ バー端面の劣化が生じたときにはその部位のみを切断 して，再生使用ができるようになっている利点があ る.ファイバー先端レーザー・ビームの広がり角は 4 度と 8 度の 2 種類あり，照射部位により交換できる。 安全装置として，レーザーが発振されているときには 常に警報音が鳴っている，ガスジェット・システムで 吸引系の閉塞状態が生じたとき，警報音が 2 段階で鳴 り，自動的に送気が停止するように作られている，術 者のレーザー光よりの眼球保護のために内視鏡接眼部 に専用フィルターがある. 使用操作は，パワー出力, 時間, ガス流量を決め, フットスイッチの操作のみで 簡単明瞭である.この器械による高出力における粘 膜, 実質臟器照射の影響についての心゙る.

\section{Laser 光線の創㑺治病に及ぼす影響に 関する基礎的研究}

慶応大 外科

$\begin{array}{ll}\text { 磯部 潔 } & \text { 吉野肇一 } \\ \text { 山藤和夫 } & \text { 石引久弥 } \\ \text { 阿部令彦 } & \\ \text { 薬化学研 } & \\ \text { 柴田徹一 } & \end{array}$

目的 近年 Laser 光線の医療領域への応用はめざ ましいものがある.しかし Laser 光線の創傷治癒に およぼす影響に関する基礎的検討の報告は少ない。そ こでこの問題についての検討を実験的に行なった.
対象および方法 体重約 $300 \mathrm{~g}$ の雄性ウィス夕一系 ラット48匹を対象とした。 ラットの背部に直径 $1 \mathrm{~cm} の$ 皮膚全層の久損創を鋭利なメスで 4 つ作製した。同部 に炭酸ガス Laser 光線を defocused beam で軽度 $(0.78 \mathrm{sec} / 50 \mathrm{~W})$, 中等度 $(0.75 \mathrm{sec} / 50 \mathrm{~W})$, 強度 (1. $5 \mathrm{sec} / 150 \mathrm{~W})$ と照射を行ない, 対照の非照射群を 含めて $0 ， 2 ， 4 ， 7 ， 14 ， 28$ 日 と経時的に屠殺し， 創傷治癒の状態を組織学的に検討した．組織学的には 創の浸出と炎症性細胞浸潤，上皮化，血管新生と肉芽 形成などの項目について検討し，それぞれの所見を総 合して創傷治癒の指標とした。

成績および考察 対照の創, すなわち Laser 光線 の非照射群では組織学的には創傷治瘺が最も早く良好 であった. Laser 光線照射群では, Laser 光線の量が 多くなるほど創傷治瘾過程の遅延が誋められた。すな わち Laser 光線は，照射部に火傷を与え，局所の炎 症性反応を増強させ, 創傷治療経過を遷延させると考 えられた。 また軽度の Laser 光線は，皮膚欠損創の 上皮化に対しては大きな影響を与えないが，新生肉芽 の形成を抑制遅延させると考えられた。

これらの創部組織の collagen 定量のため, hychoxyproline の定量も合わせて行なった。

（本研究は昭和53年度文部省科学研究費補助金, 試 験研究(2)387109による)

82.

\section{レーザーメスの安全システム}

\section{日本赤外線工業桻} 井上均杉山征司 条永徳博 東京農工大 西坂烊! 東大 医用電子研 井原音夫 中島正治 渥美 和彦

レーザー医療装置が今後急速に普及する上で，装置 の安全対策は今後非常に重要な要因となろう。一般に レーザー機器の安全性に関しては, 設置条件, 使用条 件，等を含めた総合的な判断が必要とされるが，ここ では特にハードウェア側の対策について述べる.

先ず第一に装置が故障を起さないことは当然として も，万一故障しても危険な状態へ移行する直前にこれ を検知するか，あるいは故障の程度によってはそのま ま装置が稼動出来るような融通性を持たせることが必 要とされる。このためには必要な数だけのセンサ群が 